\title{
Support and Size Effects of Activated Hydrotalcites for Precombustion $\mathrm{CO}_{2}$ Capture
}

\author{
Niels N. A. H. Meis, Johannes H. Bitter, and Krijn P. de Jong* \\ Inorganic Chemistry and Catalysis, Department of Chemistry, Debye Institute for Nanomaterials Science, \\ Utrecht University, P.O. Box 80 083, 3508 TB Utrecht, The Netherlands
}

A series of $\mathrm{Mg}-\mathrm{Al}$ hydrotalcites (HTs) with lateral platelet sizes ranging from $40 \mathrm{~nm}$ to $2 \mu \mathrm{m}$ were prepared hydrothermally. Small HT platelets $(\sim 20 \mathrm{~nm})$ were obtained by deposition onto a carbon nanofiber (CNF) support. The $\mathrm{CO}_{2}$ sorption capacity at $523 \mathrm{~K}$ for the activated unsupported HT was low $\left(\sim 0.1 \mathrm{mmol} \cdot \mathrm{g}^{-1}\right)$, regardless of the platelet size of the HT precursor. In addition, no relation was found between the $\mathrm{CO}_{2}$ sorption properties of activated HTs and their specific surface area. The sorption capacity of the activated CNFsupported HTs was increased, depending on the HT loading, by an order of magnitude $\left(1.3-2.5 \mathrm{mmol} \cdot \mathrm{g}_{\mathrm{HT}}{ }^{-1}\right)$ compared to that of the activated unsupported HT. We propose that the $\mathrm{CO}_{2}$ sorption capacities of HTs are determined by the amounts of low-coordination oxygen sites in the $\mathrm{Mg}(\mathrm{Al}) \mathrm{O}_{x}$ nanoparticles, which is highest on supported HTs.

\section{Introduction}

Carbon capture and storage (CCS) is an option to decrease the vast amounts of $\mathrm{CO}_{2}\left(28 \mathrm{Gt}\right.$ in $\left.2005^{1}\right)$ released into the atmosphere through fossil fuel utilization. ${ }^{2} \mathrm{CO}_{2}$ capture can be divided in two classes. The first of theses is end-of-pipe capture, for example, at power plants; this is the so-called postcombustion capture. Alternatively, $\mathrm{CO}_{2}$ affiliated with the production of hydrogen, for example, through the water-gas shift reaction (WGSR: $\mathrm{CO}+\mathrm{H}_{2} \mathrm{O} \leftrightarrow \mathrm{CO}_{2}+\mathrm{H}_{2}$ ) can be captured, preventing the release of $\mathrm{CO}_{2}$ and driving the equilibrium of the reaction to the hydrogen side; this is one of the options for precombustion capture. For postcombustion capture, the amines used commercially are corrosive, so special reactor materials are needed. ${ }^{3}$ Alternatives based on solid sorbents involve modified SBA1 $5^{4-6}$ and MCM41 amines, ${ }^{4,5}$ metal-organic frameworks (MOFs), ${ }^{7-10}$ and zeolitic imidazolate frameworks (ZIFs). ${ }^{11,12}$ For precombustion capture, high temperatures $\left(>250{ }^{\circ} \mathrm{C}\right)$ are required. Most of the studied materials, such as lithium zirconates, ${ }^{13-16}$ sodium zirconates, ${ }^{17,18} \mathrm{CaO},{ }^{19-21}$ basic alumina, ${ }^{22}$ and carbon-based adsorbents, ${ }^{23-25}$ do not meet the required properties with respect to sorption capacities, kinetics, and mechanical strength. Optimal sorbents for precombustion use should display properties such as selectivity toward $\mathrm{CO}_{2}$, a high adsorption capacity at high temperatures $(>523 \mathrm{~K})$, adequate adsorption and desorption kinetics at operating conditions (facile regeneration), long-term stability upon cyclic use, adequate mechanical strength, and low costs. A number of solid basic oxides, especially hydrotalcites, are promising as reusable sorbent. ${ }^{26-29}$ Hydrotalcites (HTs) belong to the class of anionic clay minerals also known as layered double hydroxides. The structure of HTs closely resembles that of brucite, $\mathrm{Mg}(\mathrm{OH})_{2}$, where $\mathrm{Mg}^{2+}$ is octahedrally coordinated by hydroxyl groups. These octahedra share adjacent edges to form sheets or layers. In HTs, some of the $\mathrm{Mg}^{2+}$ ions are replaced by $\mathrm{Al}^{3+}$ ions. This results in positively charged layers, which are balanced by charge-compensating anions (e.g., $\mathrm{Cl}^{-}, \mathrm{Br}^{-}, \mathrm{CO}_{3}{ }^{2-}, \mathrm{I}^{-}, \mathrm{NO}_{3}{ }^{-}, \mathrm{OH}^{-}, \mathrm{SO}_{4}{ }^{2-}$ ) located in the interlayer region, where hydrating water molecules are also accommodated. HTs have received considerable attention in recent years because of their wide range of applications, such as base

* To whom correspondence should be addressed. E-mail: K.P.dejong@uu.nl. catalysts, ${ }^{30-34}$ ion exchangers, ${ }^{35,36}$ polymer stabilizers, and drug targets. ${ }^{37}$ The edges, and thus the lateral dimensions of the HTs, have a significant influence on their catalytic behavior. ${ }^{30,32,38}$ Previous work from our group ${ }^{30}$ showed an increase in activity in base catalysis with decreasing platelet size for activated HTs (self-condensation of acetone). It was concluded that only the basic sites at the edges of the hydrotalcite platelets were involved in this low-temperature reaction $(273 \mathrm{~K})$. In this work, we report on the structure-activity relationship of the $\mathrm{Mg}-\mathrm{Al}$ hydrotalcite platelet size before activation and the textural properties of the activated materials with their $\mathrm{CO}_{2}$ capture properties. The samples were characterized using X-ray diffraction (XRD), scanning electron microscopy (SEM), transmission electron microscopy (TEM), and nitrogen physisorption.

\section{Experimental Section}

2.1. Preparation of Unsupported Hydrotalcites. To an aqueous solution $(150 \mathrm{~mL})$ containing $0.7 \mathrm{~mol}$ of $\mathrm{NaOH}$ and 0.09 mol of $\mathrm{Na}_{2} \mathrm{CO}_{3}$ was added dropwise an aqueous solution (70 mL) of $0.1 \mathrm{~mol}$ of $\mathrm{Mg}\left(\mathrm{NO}_{3}\right)_{2} \cdot 6 \mathrm{H}_{2} \mathrm{O}$ and $0.05 \mathrm{~mol}$ of $\mathrm{Al}\left(\mathrm{NO}_{3}\right)_{3} \cdot 9 \mathrm{H}_{2} \mathrm{O}$. The resulting white suspension was aged at $298 \mathrm{~K}$ for $24 \mathrm{~h}$ under vigorous stirring. Subsequently, the suspension was filtered and washed extensively with demineralized water. The sample, further denoted as $\mathrm{HT}_{298}$, was dried for $24 \mathrm{~h}$ at $393 \mathrm{~K}$. To increase the crystallite size of the HT, the aging was also performed at 313,333 , and $353 \mathrm{~K}$. These as-synthesized samples are further denoted as $\mathrm{HT}_{313}, \mathrm{HT}_{333}$, and $\mathrm{HT}_{353}$. Aging at higher temperatures (i.e., 373, 393, 413, and $433 \mathrm{~K}$ ) was performed in an autoclave. The synthesis mixture of $\mathrm{NaOH}, \mathrm{Na}_{2} \mathrm{CO}_{3}, \mathrm{Mg}\left(\mathrm{NO}_{3}\right)_{2} \cdot 6 \mathrm{H}_{2} \mathrm{O}$, and $\mathrm{Al}\left(\mathrm{NO}_{3}\right)_{3} \cdot 9 \mathrm{H}_{2} \mathrm{O}$ as described above was first stirred for $1 \mathrm{~h}$ at room temperature. Next, the precipitate was poured into a Teflon holder, which was placed into a stainless steel rotating autoclave, where the sample was aged for $16 \mathrm{~h}$ at the desired temperature. Subsequently, the suspension was filtered, washed extensively with demineralized water, and dried for $24 \mathrm{~h}$ at $393 \mathrm{~K}$. These assynthesized samples are further denoted as $\mathrm{HT}_{373}, \mathrm{HT}_{393}, \mathrm{HT}_{413}$, and $\mathrm{HT}_{433}$.

Preparation of Hydrotalcites Using the Urea Procedure. ${ }^{39}$ An aqueous solution $(150 \mathrm{~mL})$ of $0.1 \mathrm{~mol}$ of $\mathrm{Mg}\left(\mathrm{NO}_{3}\right)_{2} \cdot 6 \mathrm{H}_{2} \mathrm{O}$, $0.05 \mathrm{~mol}$ of $\mathrm{Al}\left(\mathrm{NO}_{3}\right)_{3} \cdot 9 \mathrm{H}_{2} \mathrm{O}$, and $0.75 \mathrm{~mol}$ of urea was 
vigorously stirred and heated at $363 \mathrm{~K}$ and kept at this temperature for $24 \mathrm{~h}$. The $\mathrm{pH}$ increased from 3.0 to $\sim 9.0$ at the end of the reaction. The resulting white suspension was filtered, washed extensively with demineralized water, and dried at 393 $\mathrm{K}$ for $24 \mathrm{~h}$. This as-synthesized sample is further denoted as $\mathrm{HT}_{\text {urea }}$.

2.2. Preparation of Supported Hydrotalcites. Carbon Nanofiber Growth. A silica-supported nickel catalyst with a metal loading of $20 \mathrm{wt} \%$ was prepared by deposition precipitation using the hydrolysis of urea at $363 \mathrm{~K} .{ }^{40}$ Silica $(8.5 \mathrm{~g})$, nickel nitrate $(10.6 \mathrm{~g})$, and urea $(7.9 \mathrm{~g})$ were suspended in $1 \mathrm{~L}$ of demineralized water and vigorously stirred. The reaction mixture was heated at $363 \mathrm{~K}$ and kept at this temperature for $16 \mathrm{~h}$. The resulting green suspension was filtered, washed extensively with demineralized water, and dried at $393 \mathrm{~K}$ for $24 \mathrm{~h}$. A sieve fraction of $425-850 \mu \mathrm{m}$ of the catalyst precursor was calcined in static air at $873 \mathrm{~K}\left(5 \mathrm{~K} \cdot \mathrm{min}^{-1}\right)$ for $3 \mathrm{~h}$. Next, the Ni catalyst precursor $(5.0 \mathrm{~g})$ was reduced in situ at $973 \mathrm{~K}$ in a fixed-bed reactor for $2 \mathrm{~h}$ in a $30 \% \mathrm{H}_{2} / \mathrm{N}_{2}$ flow $\left(800 \mathrm{~mL} \cdot \mathrm{min}^{-1}\right)$. After the temperature had been decreased to $823 \mathrm{~K}$, synthesis gas $(33 \%$ $\mathrm{CO} / 13 \% \mathrm{H}_{2}$ ) balanced with $\mathrm{N}_{2}$ was passed through the reactor for $24 \mathrm{~h}$ at a pressure of $2 \mathrm{bar}$ in a total flow of $800 \mathrm{~mL} \cdot \mathrm{min}^{-1}$. Removal of the growth catalyst and oxidation of the carbon nanofiber (CNF) was performed as reported in the literature ${ }^{41,42}$ using subsequent treatments in aqueous $1 \mathrm{M} \mathrm{KOH}$ and concentrated $\mathrm{HNO}_{3}$.

CNF-Supported Hydrotalcites. To prepare supported $\mathrm{Mg}-\mathrm{Al}$ hydrotalcites $[\mathrm{Mg} / \mathrm{Al}=2$, (at/at)], $5.0 \mathrm{~g}$ of CNF was impregnated in a $250-\mathrm{mL}$ round-bottom flask with a solution containing $3.3 \mathrm{~mL}$ of $\mathrm{Mg}\left(\mathrm{NO}_{3}\right)_{2}(1.4 \mathrm{M})$ and $\mathrm{Al}\left(\mathrm{NO}_{3}\right)_{3}(0.7 \mathrm{M})$. After this mixture had been dried for $1 \mathrm{~h}$ at $393 \mathrm{~K}$, a solution of $3.0 \mathrm{~mL}$ $\mathrm{NaOH}(8.3 \mathrm{M})$ and $\mathrm{Na}_{2} \mathrm{CO}_{3}(0.56 \mathrm{M})$ was added. Aging was performed in a water-saturated atmosphere under a nitrogen flow $\left(7 \mathrm{~mL} \cdot \mathrm{min}^{-1}\right)$ for $16 \mathrm{~h}$ at $333 \mathrm{~K}$ and was followed by extensive washing with demineralized water and drying at $393 \mathrm{~K}$ for $24 \mathrm{~h}$. This as-synthesized sample is denoted as $\mathrm{HT}_{10} \mathrm{CNF}$, with the number 10 referring to the weight loading (\%) of HT deposited on CNF. The reported nominal weight loadings are close to the actual loadings, as reported earlier. ${ }^{32}$ A second sample was prepared as described above with a solution containing $3.3 \mathrm{~mL}$ of $\mathrm{Mg}\left(\mathrm{NO}_{3}\right)_{2}(0.7 \mathrm{M})$ and $\mathrm{Al}\left(\mathrm{NO}_{3}\right)_{3}(0.35 \mathrm{M})$. This as-synthesized sample is denoted as $\mathrm{HT}_{5}-\mathrm{CNF}$. A third sample was prepared as described above. After that, the synthesis procedure was repeated once. This as-synthesized sample is denoted as $\mathrm{HT}_{18}$-CNF. General supported samples will be referred to as HT-CNF.

2.3. Characterization. Powder X-ray diffraction (XRD) patterns were measured using a Bruker-AXS D8 advance powder diffraction apparatus equipped with an automatic divergence slit (filtered Co $\mathrm{K}_{\alpha}$ radiation, $\lambda=1.79026 \AA$ ). $\mathrm{N}_{2}$ physisorption measurements were performed using a Micromeritics Tristar 3000 analyzer after the samples had been dried at $393 \mathrm{~K}$ in a vacuum for at least $20 \mathrm{~h}$ prior to the measurements; pore volume was measured at at $P / P_{0}=0.995 . \mathrm{CO}_{2}$-loaded samples $\left(\mathrm{HT}_{\mathrm{act}-\mathrm{CO}_{2}}\right)$ for nitrogen physisorption were cooled to room temperature after the adsorption step (vide infra). SEM micrographs were obtained using a Philips XL30FEG electron microscope equipped with an energy-dispersive X-ray (EDX) detector for elemental analysis. TEM micrographs were obtained with an FEI Technai 20 FEG instrument equipped with an EDX detector operating at $200 \mathrm{kV}$. TEM samples were dispersed on a holey carbon film supported on a copper grid. A Branson 450-W Sonifier was used for ultrasonic treatment for $1 \mathrm{~h}$ at $323 \mathrm{~K}$.
Table 1. Experimental Conditions for Sorption Measurements with $2 \mathrm{~g}$ of $\mathrm{HT}_{T \text {-act }}$ or $5 \mathrm{~g}$ of $\mathrm{HT}_{\text {act }}-\mathrm{CNF}$

\begin{tabular}{lcll}
\hline & $\begin{array}{c}\text { flow } \\
\left(\mathrm{mL} \cdot \mathrm{min}^{-1}\right)\end{array}$ & \multicolumn{1}{c}{ composition } & \multicolumn{1}{c}{ temp $(\mathrm{K})$} \\
\hline activation & 30 & $100 \% \mathrm{~N}_{2}$ & $323-773\left(5 \mathrm{~K} \cdot \mathrm{min}^{-1}, 1 \mathrm{~h}\right)$ \\
adsorption & 30 & $83 \% \mathrm{~N}_{2} / 12 \%$ & $523(\operatorname{max~} 30 \mathrm{~min})$ \\
& & $\mathrm{H}_{2} \mathrm{O} / 5 \% \mathrm{CO}_{2}$ & \\
desorption & 30 & $100 \% \mathrm{~N}_{2}$ & $523-773\left(5 \mathrm{~K} \cdot \mathrm{min}^{-1}, 1 \mathrm{~h}\right)$
\end{tabular}

2.4. $\mathrm{CO}_{2}$ Sorption Measurements. $\mathrm{CO}_{2}$ sorption measurements were performed in a quartz plug-flow reactor with an inner diameter of $12 \mathrm{~mm}$. The gas flows $\left(\mathrm{N}_{2}, \mathrm{CO}_{2}\right)$ were passed in downflow mode through the reactor and controlled by mass flow controllers (Brooks 5850s). The total pressure in the setup was maintained at 1.10 bar, using a backpressure controller (Brooks 5866). A tubular oven was placed around the reactor to control the process temperature. The reactor was loaded with $2.0 \mathrm{~g}$ of sample (bed height $=35 \mathrm{~mm}$ ) using a sieve fraction with particle sizes of $212-500 \mu \mathrm{m}$. For HT-CNF, the reactor was loaded with $5 \mathrm{~g}$ of sample (bed height $=85 \mathrm{~mm}$ ), which contained $0.25,0.5$, or $1.0 \mathrm{~g}$ of HT. All samples were activated by heating in $\mathrm{N}_{2}\left(30 \mathrm{~mL} \cdot \mathrm{min}^{-1}\right)$ at $773 \mathrm{~K}\left(5 \mathrm{~K} \cdot \mathrm{min}^{-1}\right)$ for $1 \mathrm{~h}$ to remove $\mathrm{CO}_{2}$ and water from the starting material $\left(\mathrm{HT}_{\mathrm{act}}\right.$, activation step). The activated samples are denoted as $\mathrm{HT}_{T \text {-act }}$ and $\mathrm{HT}_{\text {act }}-\mathrm{CNF}$, where $T$ is the synthesis temperature in Kelvin and act refers to the activation step. After activation, all samples were subjected to at least two identical adsorption $(523 \mathrm{~K})$ and desorption $(773 \mathrm{~K}$ ) cycles to assess reproducibility. Conditions for the adsorption and desorption steps are given in Table 1. The total flow throughout all experiments was $30 \mathrm{~mL} \cdot \mathrm{min}^{-1}$. $\mathrm{N}_{2}$ was humidified with $\mathrm{CO}_{2}$-free water using a saturator set at $331 \mathrm{~K}$. All adsorption experiments were performed for $30 \mathrm{~min}$ in $5 \% \mathrm{CO}_{2}$. After adsorption, the system was flushed with $\mathrm{N}_{2}$. Desorption was performed by heat treatment in dry nitrogen $\left(30 \mathrm{~mL} \cdot \mathrm{min}^{-1}\right)$ at $773 \mathrm{~K}\left(5 \mathrm{~K} \cdot \mathrm{min}^{-1}\right)$ for $1 \mathrm{~h}$. To prevent gasification of the CNF support material at higher temperatures in steam, dry nitrogen was used during desorption in all measurements to obtain comparable results between $\mathrm{HT}_{T \text {-act }}$ and $\mathrm{HT}_{\text {act }}$-CNF samples. Blank measurements were performed with either a nonadsorbing material $(\mathrm{SiC})$ or $\mathrm{CNF}$, with the same particle size range and bed volume as the HT-containing material. There was no $\mathrm{CO}_{2}$ adsorption by the supports. The effluent gas was analyzed by online FT-IR spectroscopy using a Midac corporation $2000 \mathrm{M}$ series instrument. For each spectrum, eight scans were accumulated with a resolution of 4 $\mathrm{cm}^{-1}$; spectra were recorded every $13 \mathrm{~s}$. The IR cell, made of stainless steel, had a path length of $2 \mathrm{~mm}$ and contained $\mathrm{CaF}_{2}$ windows. The sample compartment was continuously purged with a stream of dry $\mathrm{N}_{2}$ to prevent interference of $\mathrm{CO}_{2}$ present in the atmosphere. A background spectrum using an empty cell was acquired prior to sorption measurements. The integrated area from 2280 to $2390 \mathrm{~cm}^{-1}$ was used to quantify the amount of $\mathrm{CO}_{2}$ in the gas phase. $\mathrm{A} \mathrm{CO}_{2}$ concentration above $100 \mathrm{ppm}$ is defined as breakthrough. From the breakthrough time and the flow and concentration, the amount of $\mathrm{CO}_{2}$ was calculated.

\section{Results and Discussion}

3.1. Characterization of Materials. To establish the crystallographic ordering and purity of the as-synthesized HT samples, XRD analysis was performed. Figure 1 shows selected XRD patterns of unsupported as-synthesized HTs $\left(\mathrm{HT}_{298}, \mathrm{HT}_{333}\right.$, $\mathrm{HT}_{373}, \mathrm{HT}_{433}$, and $\mathrm{HT}_{\text {urea }}$ ). The signals at $2 \theta \approx 13.5^{\circ}, 27.6^{\circ}$, and $40.0^{\circ}$, corresponding to the (003), (006), and (009/012) crystal planes, respectively, indicate well-formed crystalline layered structures. In addition, at high synthesis temperatures, 


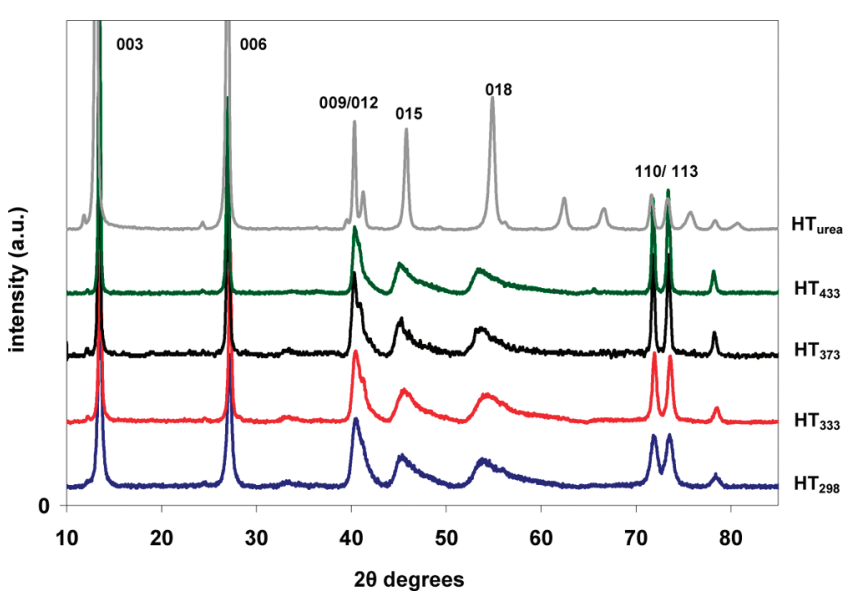

Figure 1. Selected XRD profiles of as-synthesized $\mathrm{HT}_{298}, \mathrm{HT}_{333}, \mathrm{HT}_{373}$, $\mathrm{HT}_{433}$, and $\mathrm{HT}_{\text {urea. }}$.

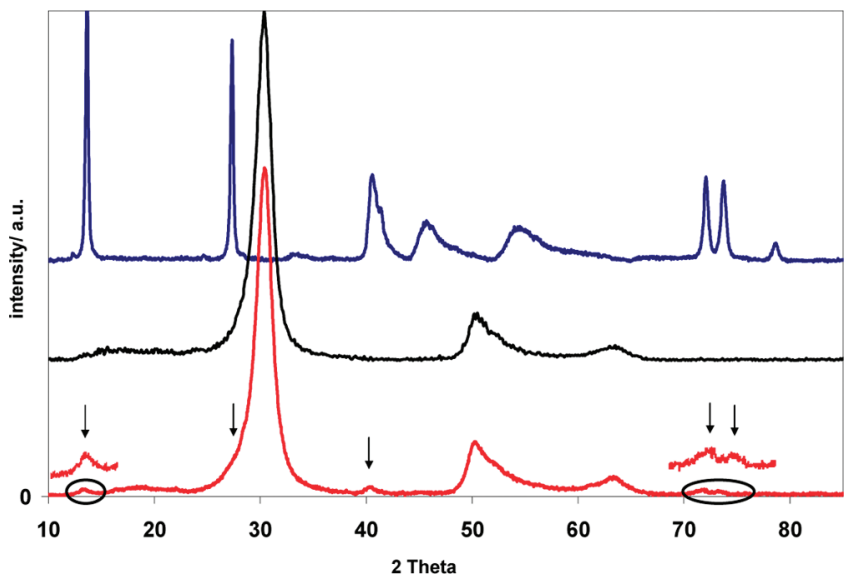

Figure 2. XRD profiles of as-synthesized $\mathrm{HT}_{333}, \mathrm{CNF}$, and $\mathrm{HT}_{10}-\mathrm{CNF}$ Arrows indicate HT peaks.

signals were detected close to the (003) and (006) signals (11.3 and $24.6^{\circ}$ ), which can be ascribed to diffractions caused by $\mathrm{K} \beta$ radiation. For all samples except $\mathrm{HT}_{\text {urea }}$, the signals were representative of HTs with interlayer carbonate. In contrast, $\mathrm{HT}_{\text {urea }}$ showed signals at $62.9^{\circ}$ and $67.1^{\circ}$ that are characteristic for a sample with hydroxylic ions $\left(\mathrm{OH}^{-}\right)$in the interlayer. ${ }^{43}$ Because the decomposition of urea takes place at relatively low $\mathrm{pH}(\mathrm{pH} \sim 6)$, the (bi)carbonate concentration in the solution will be low, and hydroxyl ions $\left(\mathrm{OH}^{-}\right)$in the interlayer are favored. To summarize, only crystalline hydrotalcites were detected by XRD, indicating the high purity of all samples. The selected $\mathrm{XRD}$ pattern of the supported hydrotalcite $\left(\mathrm{HT}_{10}-\mathrm{CNF}\right)$ is compared to those of $\mathrm{HT}_{333}$ and to pure CNF in Figure 2. In the supported sample, diffraction lines due to the presence of HT, as indicated by the arrows, can be distinguished next to the strong lines of the CNF support. From this figure, it is clear that the diffraction lines of hydrotalcite in the supported sample are broader than those of unsupported HT, which implies that the HT crystallites on the supported sample $\left(\mathrm{HT}_{10}-\mathrm{CNF}\right)$ are smaller and/or less ordered. ${ }^{44}$ In addition, the intensity of the signals for supported HT is much smaller than that for the unsupported HT sample, after identical counting times, as a result of the small HT platelets ${ }^{31}$ and/or lower amount of HT present.

The particle size and morphology of unsupported HT samples were analyzed by SEM, whereas the supported HTs were analyzed by TEM. Figure 3 shows SEM micrographs of selected hydrotalcites $\left(\mathrm{HT}_{313}, \mathrm{HT}_{373}, \mathrm{HT}_{473}\right.$, and $\left.\mathrm{HT}_{\text {urea }}\right)$. Samples pre-
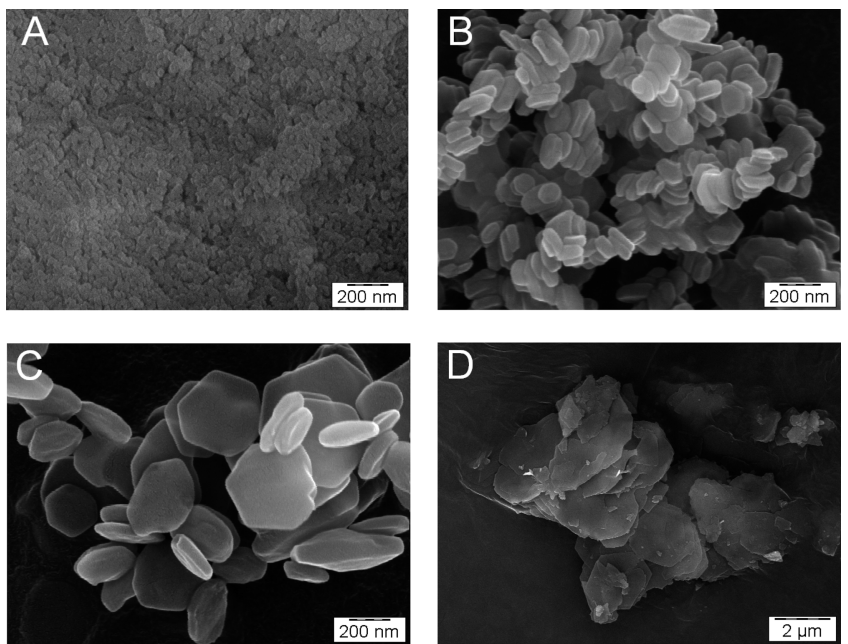

Figure 3. $\mathrm{SEM}$ micrographs of (A) $\mathrm{HT}_{313}$, (B) $\mathrm{HT}_{373}$, (C) $\mathrm{HT}_{433}$, (D) $\mathrm{HT}_{\text {urea }}$.
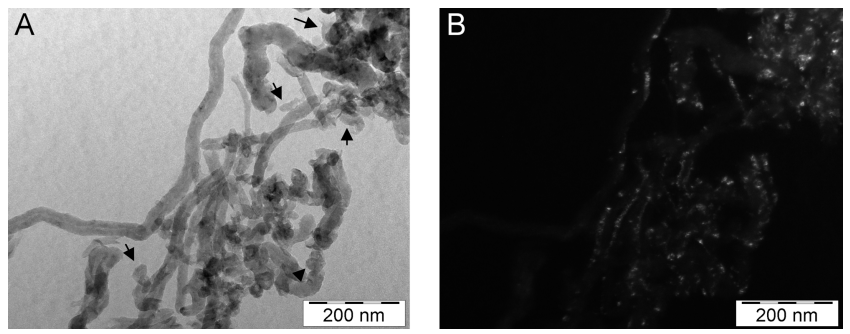

Figure 4. TEM micrographs of $\mathrm{HT}_{10}-\mathrm{CNF}$ in (A) bright field (arrows indicate HT platelets) and (B) dark field (small HT crystallites are visible).

pared using $\mathrm{NaOH} / \mathrm{Na}_{2} \mathrm{CO}_{3}$ as a base (Figure $3 \mathrm{~A}-\mathrm{C}$ ) showed regular hexagonally shaped HT platelets. The micrographs highlight the difference in lateral platelet size due to the aging temperature, with an increase in size occurring with increasing temperature. When urea was used as the precipitant, very large HT platelets $(2 \mu \mathrm{m}$, Figure 3D) were obtained, in line with literature reports. ${ }^{39,45}$ Figure 4 shows selected bright- and darkfield TEM micrographs of $\mathrm{HT}_{10}$-CNF. In bright-field mode, HTs are difficult to distinguish from carbon, because of a similarity in density. In dark-field mode (i.e., diffraction contrast imaging), the small HT crystallites were easier to observe (Figure 4). The dark-field micrographs revealed more HTs than could be detected in bright-field mode. For clarity, the arrows in Figure 4A indicate some of the HT platelets.

An overview of the average lateral platelet sizes as a function of the aging temperature, based on SEM and TEM measurements to determine the platelet sizes of 30 individual HT platelets, is shown in Figure 5. Clearly, unsupported assynthesized HT samples showed an increase in lateral platelet size with increasing synthesis temperature. The average crystalline platelets increased from $35 \mathrm{~nm}\left(\mathrm{HT}_{298}\right)$ to $300 \mathrm{~nm}\left(\mathrm{HT}_{433}\right)$. $\mathrm{HT}_{\text {urea }}$ had the largest lateral platelet size $(2 \mu \mathrm{m})$, whereas supported hydrotalcites displayed the smallest crystalline platelets $(\sim 20 \mathrm{~nm})$. In conclusion, the HT platelets were tuned from $20 \mathrm{~nm}$ to $2 \mu \mathrm{m}$, and all HT precursor samples showed good crystallinity.

3.2. $\mathrm{CO}_{2}$ Adsorption and Desorption Kinetics. Prior to sorption measurements, all samples were activated at $773 \mathrm{~K}$ in $\mathrm{N}_{2}$. Representative breakthrough curves for $\mathrm{CO}_{2}$ adsorption at $523 \mathrm{~K}$ on these activated HTs are shown in Figure 6a. Note that, after activation, the hydrotalcite material still retained its mesoscopic shape (i.e., the platelets were still present), but XRD 


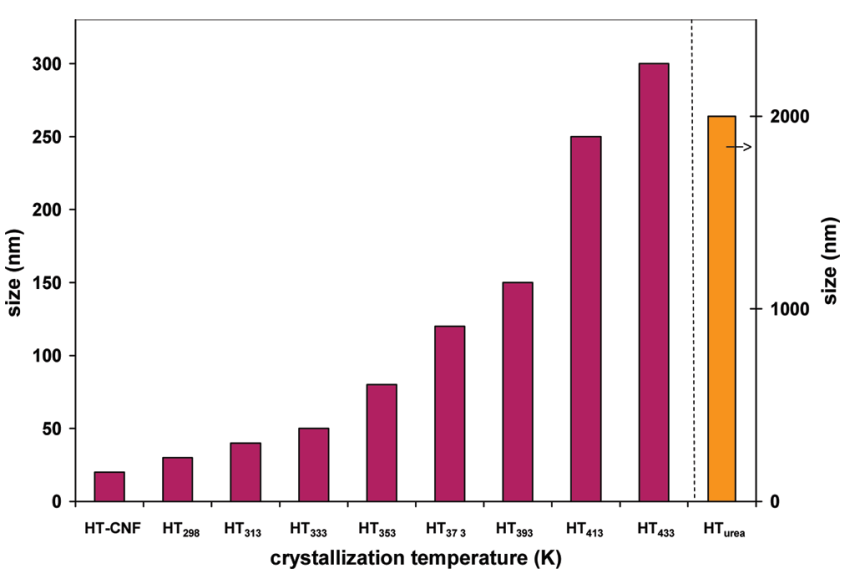

Figure 5. Effect of average platelet size on crystallization temperature of as-synthesized HTs.
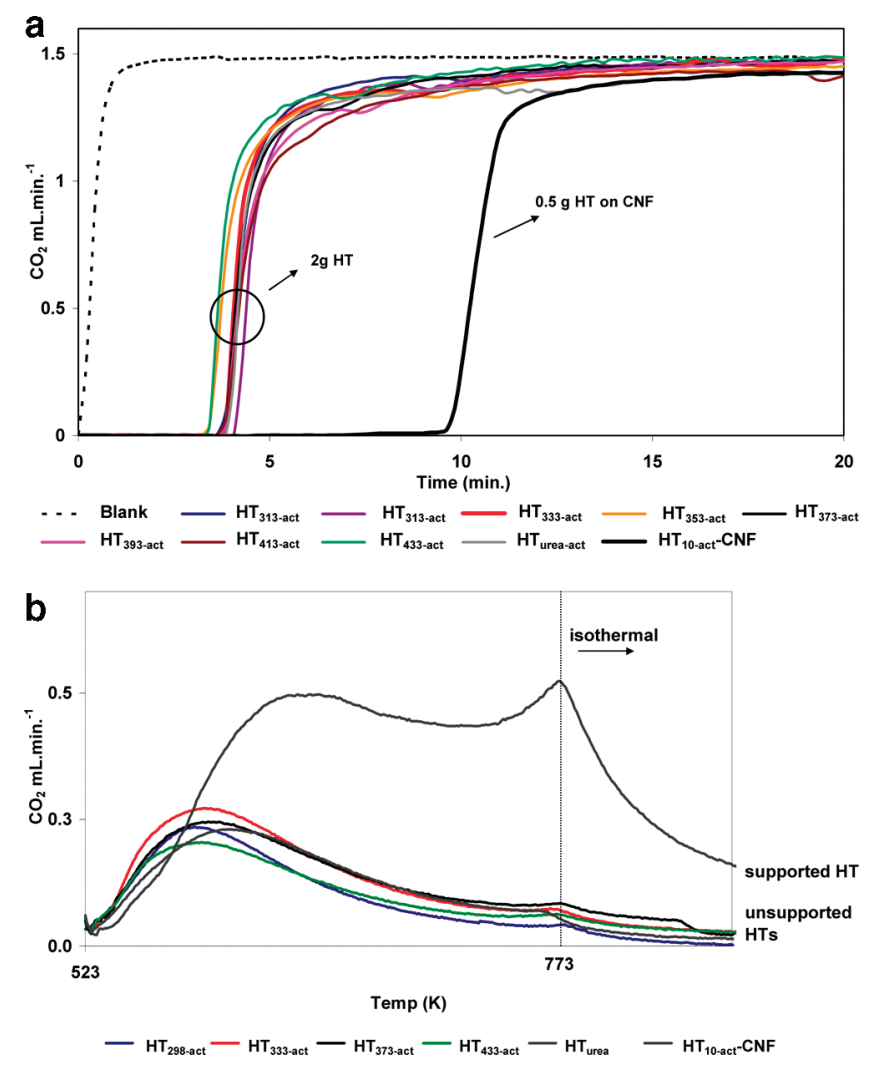

Figure 6. (a) Representative breakthrough curves of activated HTs (2 g) and activated $\mathrm{HT}_{10}-\mathrm{CNF}\left(5 \mathrm{~g}\right.$ ) (flow: $25 \mathrm{~mL} \cdot \mathrm{min}^{-1} \mathrm{~N}_{2}, 3.5 \mathrm{~mL} \cdot \mathrm{min}^{-1} \mathrm{H}_{2} \mathrm{O}$, and $1.5 \mathrm{~mL} \cdot \mathrm{min}^{-1} \mathrm{CO}_{2}$ at $523 \mathrm{~K}$ ). (b) Selected representative desorption profiles of activated $\mathrm{HTs}$ and activated $\mathrm{HT}_{10} \mathrm{CNF}$ (flow: $30 \mathrm{~mL} \cdot \mathrm{min}^{-1} \mathrm{~N}_{2}$, $523-773 \mathrm{~K}, 1 \mathrm{~h})$.

revealed broad $\mathrm{Mg}(\mathrm{Al}) \mathrm{O}_{x}$ diffractions. The activated samples are denoted as $\mathrm{HT}_{\mathrm{act}}$ and $\mathrm{HT}_{\mathrm{act}} \mathrm{CNF}$, where the subscript "act" denotes the activated material $\left[\mathrm{Mg}(\mathrm{Al}) \mathrm{O}_{x}\right]$ after heat treatment. All activated unsupported HTs showed, within experimental error, the same breakthrough times, which corresponded to a $\mathrm{CO}_{2}$ capacity of approximately $0.1 \mathrm{mmol} \cdot \mathrm{g}^{-1}$, irrespective of the original platelet size. For the supported activated HTs, the breakthrough times were significantly longer (Figure 6a). Even though these samples contained only 5, 10, and $18 \mathrm{wt} \% \mathrm{HT}$, breakthrough times were $10.1 \mathrm{~min}$ for $\mathrm{HT}_{5 \text {-act }} \mathrm{CNF}, 9.5 \mathrm{~min}$ for $\mathrm{HT}_{10 \text {-act }}{ }^{-\mathrm{CNF}}$ (shown), and $13.0 \mathrm{~min}$ for $\mathrm{HT}_{18 \text {-act }} \mathrm{CNF}$, which correspond to capacities of $2.5,1.3$, and $1.7 \mathrm{mmol} \cdot \mathrm{g}_{\mathrm{HT}}{ }^{-1}$, that is, an order of magnitude higher compared to those for the activated unsupported HTs. A selected number of desorption

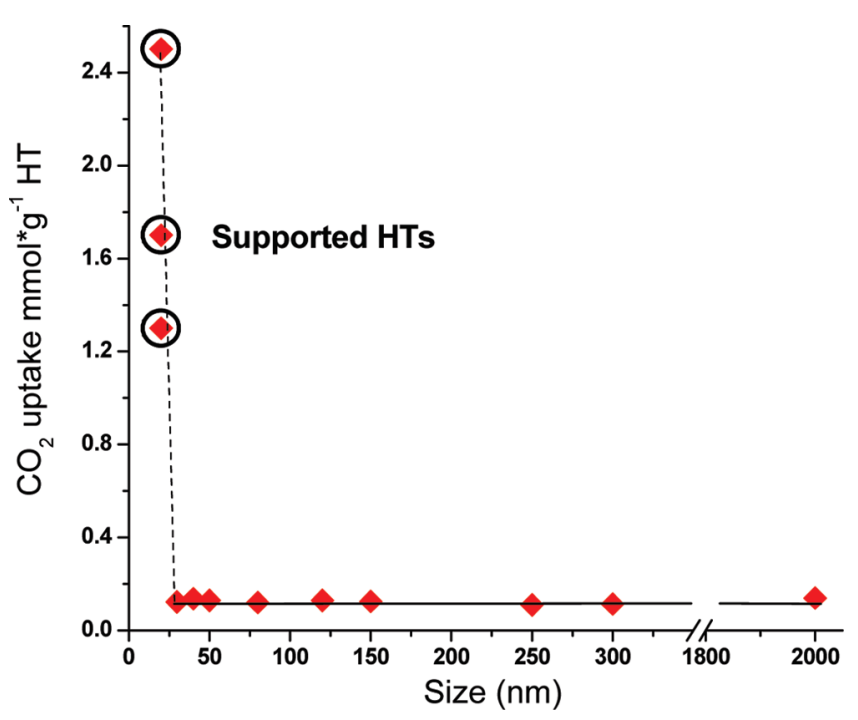

Figure 7. $\mathrm{CO}_{2}$ capacities at $523 \mathrm{~K}$ of all activated (supported) HTs and their laterals sizes. The supported samples have a 10-25-fold higher capacities than the unsupported samples.

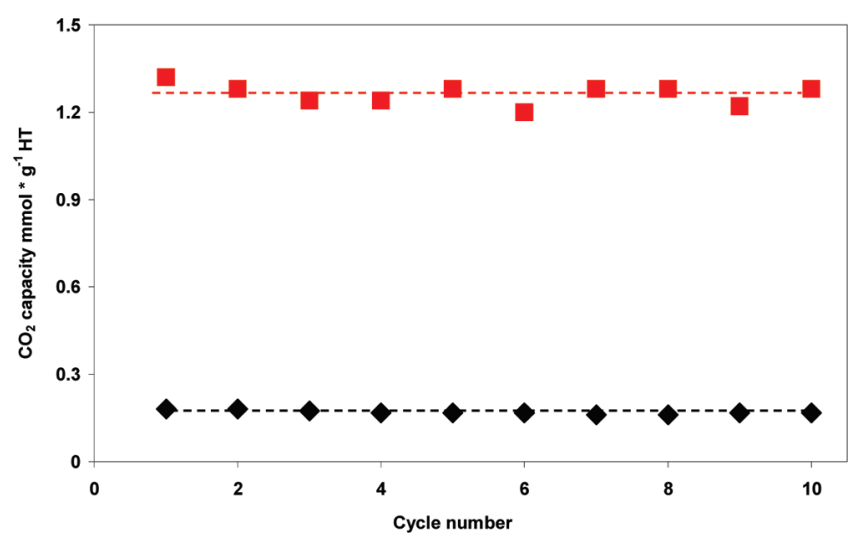

Figure 8. $\mathrm{CO}_{2}$ capacity as function of adsorption-desorption cycles for two selected samples: unsupported $\mathrm{HT}_{333 \text {-act }}(\downarrow)$ and $\mathrm{HT}_{10 \text {-act }} \mathrm{CNF}(\boldsymbol{\square})$.

profiles are shown in Figure 6b. Under these dry conditions, all activated unsupported HTs exhibited similar desorption characteristics. Desorption of the activated supported sample started at a higher temperature compared to that of the activated unsupported HT, and the first desorption maximum of $\mathrm{HT}_{10-\text { act }^{-}}$ CNF occurred at $580 \mathrm{~K}$. These details point to stronger bonding of adsorbed $\mathrm{CO}_{2}$. The high-temperature desorption peak (773 K) is more pronounced with HT-CNF, which is more likely related to absorption. Note that the presence of steam during desorption will most likely negatively affect the cycle stability of the CNFsupported materials.

Figure 7 summarizes the adsorption capacity at $532 \mathrm{~K}$ of all samples as a function of their original HT platelet size. Unsupported hydrotalcites (platelet size between $30 \mathrm{~nm}$ and 2 $\mu \mathrm{m})$ evidently all have an invariant adsorption capacity $(\sim 0.1$ $\left.\mathrm{mmol} \cdot \mathrm{g}^{-1}\right)$. Lemonidou et al. ${ }^{20}$ also reported that the $\mathrm{CO}_{2}$ capacity did not depend on size for $\mathrm{CaO}$-based materials. However, their materials had sizes in the range of $1-10 \mu \mathrm{m}$, whereas our precursor samples had sizes from $35 \mathrm{~nm}$ to $2 \mu \mathrm{m}$. Surprisingly, the supported HT samples with a platelet size of $\sim 20 \mathrm{~nm}$ had much higher capacities, depending on the HT loading, of $1.3-2.5 \mathrm{mmol} \cdot \mathrm{g}_{\mathrm{HT}}{ }^{-1}$. Figure 8 shows the $\mathrm{CO}_{2}$ sorption capacities of $\mathrm{HT}_{333 \text {-act }}$ and $\mathrm{HT}_{10 \text {-act }} \mathrm{CNF}$ as a function of the number of adsorption-desorption cycles. Clearly, the materials showed stable behavior. 
Table 2. Physicochemical Properties of the Hydrotalcites HT $_{\text {as, }}$ $\mathrm{HT}_{\text {act }}$, and $\mathrm{HT}_{\text {act-CO}}$

\begin{tabular}{|c|c|c|c|c|c|c|}
\hline \multirow[b]{2}{*}{ sample } & \multicolumn{2}{|c|}{$\mathrm{HT}_{\text {as }}$} & \multicolumn{2}{|c|}{$\mathrm{HT}_{\text {act }}$} & \multicolumn{2}{|c|}{$\mathrm{HT}_{\text {act- }-\mathrm{CO}_{2}}$} \\
\hline & $\underset{\left(\mathrm{m}^{2} \cdot \mathrm{g}^{-1}\right)}{S_{\mathrm{BET}}}$ & $\begin{array}{c}V_{\text {tot }} \\
\left(\mathrm{cm}^{3} \cdot \mathrm{g}^{-1}\right)\end{array}$ & $\underset{\left(\mathrm{m}^{2} \cdot \mathrm{g}^{-1}\right)}{S_{\mathrm{BET}}}$ & $\begin{array}{c}V_{\text {tot }} \\
\left(\mathrm{cm}^{3} \cdot \mathrm{g}^{-1}\right)\end{array}$ & $\underset{\left(\mathrm{m}^{2} \cdot \mathrm{g}^{-1}\right)}{S_{\mathrm{BET}}}$ & $\begin{array}{c}V_{\text {tot }} \\
\left(\mathrm{cm}^{3} \cdot \mathrm{g}^{-1}\right)\end{array}$ \\
\hline $\mathrm{HT}_{298}$ & 100 & 0.6 & 262 & 0.86 & 126 & 0.27 \\
\hline $\mathrm{HT}_{313}$ & 93 & 0.67 & 125 & 0.74 & 216 & 0.57 \\
\hline $\mathrm{HT}_{333}$ & 53 & 0.35 & 68 & 0.46 & 117 & 0.41 \\
\hline $\mathrm{HT}_{353}$ & 47 & 0.4 & 83 & 0.45 & 50 & 0.44 \\
\hline $\mathrm{HT}_{373}$ & 24 & 0.11 & 68 & 0.16 & 127 & 0.44 \\
\hline $\mathrm{HT}_{393}$ & 21 & 0.09 & 209 & 0.22 & 23 & 0.14 \\
\hline $\mathrm{HT}_{413}$ & 19 & 0.07 & 157 & 0.17 & 172 & 0.18 \\
\hline $\mathrm{HT}_{433}$ & 15 & 0.07 & 183 & 0.17 & 139 & 0.2 \\
\hline $\mathrm{HT}_{\text {urea }}$ & 32 & 0.1 & 245 & 0.26 & 72 & 0.2 \\
\hline $\mathrm{HT}_{333 \text {-us }}$ & & & & & 211 & 0.77 \\
\hline $\mathrm{CNF}$ & 155 & 0.34 & & & & \\
\hline $\mathrm{HT}_{5}-\mathrm{CNF}$ & 107 & 0.29 & 124 & 0.31 & - & - \\
\hline $\mathrm{HT}_{10}-\mathrm{CNF}$ & 97 & 0.19 & 114 & 0.22 & 110 & 0.23 \\
\hline $\mathrm{HT}_{18}$-CNF & 98 & 0.18 & 105 & 0.20 & - & - \\
\hline
\end{tabular}

Because no relation could be found between platelet size and capacity, we investigated whether $\mathrm{CO}_{2}$ capture properties of the HTs were related to their textural properties, especially after activation (Table 2). In Table 2, some physicochemical properties of the unsupported HTs are listed. Micropores were not, or were hardly, present in the samples. The surface area of the as-synthesized HTs $\left(\mathrm{HT}_{\mathrm{as}}\right)$ varied from 15 to $100 \mathrm{~m}^{2} \cdot \mathrm{g}^{-1}$ and decreased with increasing platelet size (i.e., with increasing aging temperature), which is in good agreement with the literature. ${ }^{46}$ Activation (meaning heat treatment in $\mathrm{N}_{2}$ at $773 \mathrm{~K}$; see section 2.3) of the HTs $\left(\mathrm{HT}_{\mathrm{act}}\right)$ resulted in an increase in surface area and pore volume. To investigate how the textural properties of activated HTs changed after $\mathrm{CO}_{2}$ loading, nitrogen physisorption experiments were also performed on the $\mathrm{CO}_{2}$-loaded samples (Table 2, $\mathrm{HT}_{\text {act-CO }}$; see 2.4). All loaded samples showed a decrease in pore volume compared to that of activated HT, with

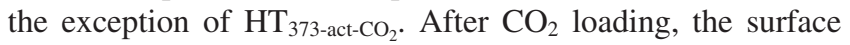
areas of samples $\mathrm{HT}_{298}, \mathrm{HT}_{333}, \mathrm{HT}_{373}$, and $\mathrm{HT}_{433}$ were in a similar range $\left(117-129 \mathrm{~m}^{2} \cdot \mathrm{g}^{-1}\right)$, whereas the surface areas of the other loaded samples $\left(\mathrm{HT}_{313}, \mathrm{HT}_{353}, \mathrm{HT}_{393}, \mathrm{HT}_{413}\right.$, and $\mathrm{HT}_{\text {urea }}$ ) varied significantly. Moreover, after being loaded with $\mathrm{CO}_{2}$, five samples decreased in surface area $\left(\mathrm{HT}_{298}, \mathrm{HT}_{353}\right.$, $\mathrm{HT}_{393}, \mathrm{HT}_{433}$, and $\left.\mathrm{HT}_{\text {urea }}\right)$, whereas the other four samples $\left(\mathrm{HT}_{313}\right.$, $\mathrm{HT}_{333}, \mathrm{HT}_{373}$, and $\mathrm{HT}_{413}$ ) exhibited an increase in surface area. Thus, both the activated HTs and the $\mathrm{CO}_{2}$-loaded samples showed nonsystematic variations of surface area and pore volume. These results indicate that there is no relation between $\mathrm{CO}_{2}$ capacity and textural properties, which is in agreement with the results of Kim and co-workers. ${ }^{47}$ The pore volumes and surface areas of the CNF-supported HTs were significantly lower than the corresponding values for CNF, which indicates a partial filling of the pores with HT (Table 2, bottom). The surface areas and pore volumes of activated supported HTs were slightly higher than those of their precursors.

As discussed above, the $\mathrm{CO}_{2}$ sorption capacity of activated unsupported HTs was found to be invariant with the surface area. Therefore, the coverage of $\mathrm{CO}_{2}$ per square nanometer must increase with decreasing surface area (see Figure 9). Now, we attempt to explain this observation. For $\mathrm{MgO}$, which has a structure similar to that of the activated HTs, the sites for $\mathrm{CO}_{2}$ adsorption are expected to associate with low-coordinated $\mathrm{O}^{2-}-\mathrm{Mg}^{2+}$ sites. ${ }^{48-58}$ In other words, the $\mathrm{C}$ of $\mathrm{CO}_{2}$ adsorbs on low-coordinated oxygen (oxygen surrounded by fewer than five atoms). We propose that the active sites for $\mathrm{CO}_{2}$ adsorption on activated $\mathrm{HTs}$ are also associated with $\mathrm{O}^{2-}-\mathrm{Mg}^{2+}$ sites $(\mathrm{MgO}$ $+\mathrm{CO}_{2} \leftrightarrow \mathrm{MgCO}_{3}$ ). During $\mathrm{CO}_{2}$ sorption, the acidic $\mathrm{CO}_{2}$ reacts with basic $\mathrm{O}^{2-}$ sites depending on their coordination. Oxygen atoms located at edges and corners of the crystal planes have

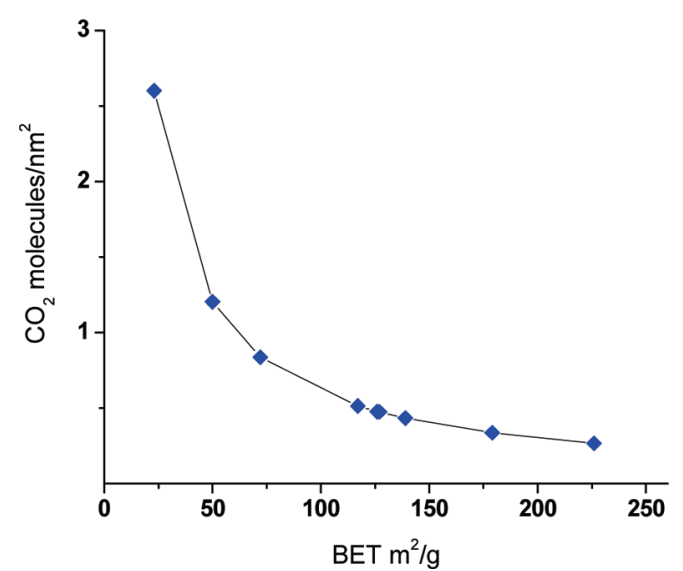

Figure 9. Effect of surface area on activated unsupported HTs: coverage of $\mathrm{CO}_{2}$ increases with decreasing surface area.

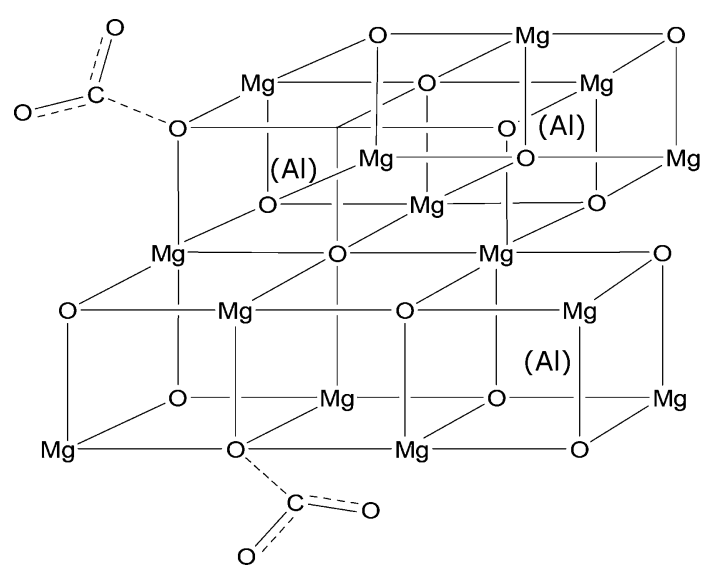

Figure 10. Corners and edges are important for $\mathrm{CO}_{2}$ adsorption.

stronger basicity than oxygen atoms in basal planes. Therefore, the energy level of surface oxygen increases with decreasing coordination number. The interactions are assumed to be mainly of the highest occupied molecular orbital (HOMO)-lowest unoccupied molecular orbital (LUMO) type. ${ }^{53}$ Consequently, the HOMO-LUMO energy gap between $\mathrm{O}^{2-}$ and $\mathrm{CO}_{2}$ is reduced on corners and edges (under coordination of oxygen), and thus, charge transfer from $\mathrm{O}^{2-}$ to $\mathrm{CO}_{2}$ will occur. Therefore, the interaction from an edge or corner $\mathrm{O}^{2-}$ anion with a $\mathrm{CO}_{2}$ molecule can lead to surface carbonate species. ${ }^{59,60}$ For $\mathrm{MgO}$ surfaces, Pettersson et al. ${ }^{59,60}$ calculated energetically favorable interactions with $\mathrm{CO}_{2}$. They concluded that, on a regular unperturbed $\mathrm{MgO}(100)$ surface, no $\mathrm{CO}_{2}$ adsorption occurs. However, three- and four-coordinated $\mathrm{O}^{2-}$ edges and corners $\left(\mathrm{O}_{3 \mathrm{c}}, \mathrm{O}_{4 \mathrm{c}}\right)$ showed a reduction in the HOMO-LUMO energy gap. Consequently, adsorption with $\mathrm{CO}_{2}$ on an edge or corner is more likely to occur (Figure 10), which illustrates our proposal. As a result of these findings, we propose that the amounts of low-coordinated oxygen in our activated unsupported samples are identical on a weight basis for all samples. After activation, the samples lose their original crystalline platelet structure and are all $\mathrm{Mg}(\mathrm{Al}) \mathrm{O}_{x}$-like, although the platelet shapes of the HTs, as visualized by SEM, remain. Apparently, larger $\mathrm{Mg}(\mathrm{Al}) \mathrm{O}_{x}$ particles contain more surface defects per unit surface area and, consequently, higher coverages of $\mathrm{CO}_{2}$ (Figure 10). We propose that the high increase in $\mathrm{CO}_{2}$ capacities of the activated supported HTs is based on a greater number of defects on the small $\operatorname{Mg}(\mathrm{Al}) \mathrm{O}_{x}$ crystals. The individual crystals are anchored on the CNF and thus have less flexibility, which might contribute to more defects and low-coordinated oxygen. In other 
words, more adsorption sites are formed in the activated supported HTs $\left[\mathrm{Mg}(\mathrm{Al}) \mathrm{O}_{x}\right]$ upon heat treatment, as result of the limited mobility. Apparently, for unsupported materials, the total numbers of adsorption sites in the reactor are similar for all samples, because the adsorption capacity is the same for all samples (Figure 6a). We speculate that the number of defects per surface area is larger for larger particles (i.e., those formed from larger HT platelets) than for the smaller particles, probably as a result of a more difficult annealing (i.e., lower mobility of ions) in larger particles during activation. Additional evidence for the role of low-coordination sites comes from the use of an unsupported ultrasonic-treated HT sample (data not shown). Sonication is expected to create defects on the surface/edges of the HT. ${ }^{61,62}$ Indeed, the capacity of a sonicated sample increased to $0.2 \mathrm{mmol} \cdot \mathrm{g}^{-1}$ as compared to the $0.1 \mathrm{mmol} \cdot \mathrm{g}^{-1}$ for a regular sample. Unfortunately, after the first cycle, the capacity of the sonicated sample dropped to the original value of the regular HTs.

\section{Conclusions}

In this article, we have presented a study of $\mathrm{CO}_{2}$ sorption measurements at $523 \mathrm{~K}$ on $\mathrm{Mg}-\mathrm{Al}$ hydrotalcites with lateral platelet sizes from $20 \mathrm{~nm}$ to $2 \mu \mathrm{m}$. Unsupported hydrotalcites showed an invariant and low capacity as a function of platelet size. An increase by a factor 10-25 in HT-weight-based capacities was accomplished by supporting the HTs on CNF. Nitrogen physisorption measurements showed no dependence of $\mathrm{CO}_{2}$ capacity and specific surface area for the unsupported HT. Currently, we tentatively relate the higher capacity of the activated supported samples to a higher density of lowcoordination oxygen (edges and corners) in the $\mathrm{Mg}(\mathrm{Al}) \mathrm{O}_{x}$-phase crystal interacting with the CNF surface.

\section{Acknowledgment}

This research has been carried out by Inorganic Chemistry and Catalysis, Debye Institute for Nanomaterials Science, Department of Chemistry in the CATO project (Carbon Capture, Transport and Storage). Marjan Versluijs-Helder, Cor van der Spek, and Ad Mens are thanked for SEM, TEM, and $\mathrm{N}_{2}$ physisorption measurements. Valuable input from Ruud van den Brink, Paul Cobden, Daan Jansen, and Rick Reijers (ECN, Petten, The Netherlands) is acknowledged.

\section{Literature Cited}

(1) Intergovernmental Panel on Climate Change (IPCC). Climate Change 2007: The Physical Science Basis; Cambridge University Press: Cambridge, U.K., 2007.

(2) The CATO-2 Project. http://CO2-cato.nl/.

(3) Fauth, D. J.; Frommell, E. A.; Hoffman, J. S.; Reasbeck, R. P.; Pennline, H. W. Eutectic salt promoted lithium zirconate: Novel high temperature sorbent for $\mathrm{CO}_{2}$ capture. Fuel Process. Technol. 2005, 86 (1415), 1503-1521.

(4) Hicks, J. C.; Drese, J. H.; Fauth, D. J.; Gray, M. L.; Qi, G. G.; Jones, C. W. Designing adsorbents for $\mathrm{CO}_{2}$ capture from flue gas-hyperbranched aminosilicas capable, of capturing $\mathrm{CO}_{2}$ reversibly. J. Am. Chem. Soc. 2008, 130 (10), 2902-2903.

(5) Yue, M. B.; Sun, L. B.; Cao, Y.; Wang, Y.; Wang, Z. J.; Zhu, J. H. Efficient $\mathrm{CO}_{2}$ capturer derived from as-synthesized MCM-41 modified with amine. Chem.-Eur. J. 2008, 14 (11), 3442-3451.

(6) Wang, X.; Schwartz, V.; Clark, J. C.; Ma, X.; Overbury, S. H.; Xu, X.; Song, C. Infrared Study of $\mathrm{CO}_{2}$ Sorption over "Molecular Basket" Sorbent Consisting of Polyethylenimine-Modified Mesoporous Molecular Sieve. J. Phys. Chem. C 2009, 113 (17), 7260-7268.

(7) Babarao, R.; Jiang, J. W. Molecular screening of metal-organic frameworks for $\mathrm{CO}_{2}$ storage. Langmuir 2008, 24 (12), 6270-6278.

(8) Llewellyn, P. L.; Bourrelly, S.; Serre, C.; Vimont, A.; Daturi, M.; Hamon, L.; De Weireld, G.; Chang, J. S.; Hong, D. Y.; Hwang, Y. K.;
Jhung, S. H.; Ferey, G. High uptakes of $\mathrm{CO}_{2}$ and $\mathrm{CH}_{4}$ in mesoporous metalorganic frameworks MIL-100 and MIL-101. Langmuir 2008, 24 (14), 72457250 .

(9) Finsy, V.; Ma, L.; Alaerts, L.; De Vos, D. E.; Baron, G. V.; Denayer, J. F. M. Separation of $\mathrm{CO}_{2} / \mathrm{CH}_{4}$ mixtures with the MIL-53(Al) metalorganic framework. Microporous Mesoporous Mater. 2009, 120 (3), 221227.

(10) Yazaydin, A. O. z. r.; Benin, A. I.; Faheem, S. A.; Jakubczak, P.; Low, J. J.; Willis, R. R.; Snurr, R. Q. Enhanced $\mathrm{CO}_{2}$ Adsorption in MetalOrganic Frameworks via Occupation of Open-Metal Sites by Coordinated Water Molecules. Chem. Mater. 2009, 21 (8), 1425-1430.

(11) Banerjee, R.; Phan, A.; Wang, B.; Knobler, C.; Furukawa, H.; O'Keeffe, M.; Yaghi, O. M. High-throughput synthesis of zeolitic imidazolate frameworks and application to $\mathrm{CO}_{2}$ capture. Science 2008, 319 (5865), 939-943.

(12) Liu, D. H.; Zheng, C. C.; Yang, Q. Y.; Zhong, C. L. Understanding the Adsorption and Diffusion of Carbon Dioxide in Zeolitic Imidazolate Frameworks: A Molecular Simulation Study. J. Phys. Chem. C 2009, 113 (12), 5004-5009.

(13) Ida, J.; Lin, Y. S. Mechanism of high-temperature $\mathrm{CO}_{2}$ sorption on lithium zirconate. Environ. Sci. Technol. 2003, 37 (9), 1999-2004.

(14) Pfeiffer, H.; Knowles, K. M. Reaction mechanisms and kinetics of the synthesis and decomposition of lithium metazirconate through solidstate reaction. J. Eur. Ceram. Soc. 2004, 24 (8), 2433-2443.

(15) Ida, J.; Xiong, R. T.; Lin, Y. S. Synthesis and $\mathrm{CO}_{2}$ sorption properties of pure and modified lithium zirconate. Sep. Purif. Technol. 2004, 36 (1), 41-51.

(16) Xiong, R. T.; Ida, J.; Lin, Y. S. Kinetics of carbon dioxide sorption on potassium-doped lithium zirconate. Chem. Eng. Sci. 2003, 58 (19), 43774385 .

(17) Zhao, T. J.; Ochoa-Fernandez, E.; Ronning, M.; Chen, D. Preparation and high-temperature $\mathrm{CO}_{2}$ capture properties of nanocrystalline $\mathrm{Na}_{2} \mathrm{ZrO}_{3}$. Chem. Mater. 2007, 19 (13), 3294-3301.

(18) Ochoa-Fernandez, E.; Ronning, M.; Grande, T.; Chen, D. Synthesis and $\mathrm{CO}_{2}$ capture properties of nanocrystalline lithium zirconate. Chem. Mater. 2006, 18 (25), 6037-6046.

(19) Han, C.; Harrison, D. P. Simultaneous shift reaction and carbon dioxide separation for the direct production of hydrogen. Chem. Eng. Sci. 1994, 49 (24B), 5875-5883.

(20) Martavaltzi, C. S.; Lemonidou, A. A. Development of new $\mathrm{CaO}$ based sorbent materials for $\mathrm{CO}_{2}$ removal at high temperature. Microporous Mesoporous Mater. 2008, 110 (1), 119.

(21) Kuramoto, K.; Fujimoto, S.; Morita, A.; Shibano, S.; Suzuki, Y.; Hatano, H.; Lin, S. Y.; Harada, M.; Takarada, T. Repetitive carbonationcalcination reactions of Ca-based sorbents for efficient $\mathrm{CO}_{2}$ sorption at elevated temperatures and pressures. Ind. Eng. Chem. Res. 2003, 42 (5), 975-981.

(22) Yong, Z.; Mata, V.; Rodrigues, A. E. Adsorption of carbon dioxide on basic alumina at high temperatures. J. Chem. Eng. Data 2000, 45 (6), $1093-1095$.

(23) Yong, Z.; Mata, V. G.; Rodrigues, A. E. Adsorption of carbon dioxide on chemically modified high surface area carbon-based adsorbents at high temperature. Adsorption 2001, 7 (1), 41-50.

(24) Kapoor, A.; Krishnamurthy, K. R.; Shirley, A. Kinetic separation of carbon dioxide from hydrocarbons using carbon molecular sieve. Gas Sep. Purif. 1993, 7 (4), 259-263.

(25) Song, H. K.; Lee, K. H. Adsorption of carbon dioxide on chemically modified carbon adsorbents. Sep. Sci. Technol. 1998, 33 (13), 2039-2057.

(26) Ding, Y.; Alpay, E. Equilibria and kinetics of $\mathrm{CO}_{2}$ adsorption on hydrotalcite adsorbent. Chem. Eng. Sci. 2000, 55 (17), 3461-3474.

(27) Ding, Y.; Alpay, E. Adsorption-enhanced steam-methane reforming. Chem. Eng. Sci. 2000, 55 (18), 3929-3940.

(28) Ding, Y.; Alpay, E. High temperature recovery of $\mathrm{CO}_{2}$ from flue cases using hydrotalcite adsorbent. Process Saf. Environ. Prot. 2001, 79 (B1), 45-51.

(29) Nataraj, S.; Carvill, B. T.; Hufton, J. R.; Mayorga, S. G.; Gaffney, T. R.; Brozozowski, J. R. Materials selectivity adsorbing $\mathrm{CO}_{2}$ from $\mathrm{CO}_{2}$ containing streams. EP Patent No. 1006079A1, 2000.

(30) Winter, F.; Wolters, M.; van Dillen, A. J.; de Jong, K. P. A hydrotalcite-based catalyst system for the single-stage liquid-phase synthesis of MIBK. Appl. Catal. A 2006, 307 (2), 231-238.

(31) Winter, F.; van Dillen, A. J.; de Jong, K. P. Supported hydrotalcites as highly active solid base catalysts. Chem. Commun. 2005, (31), 39773979.

(32) Winter, F.; Koot, V.; van Dillen, A. J.; Geus, J. W.; de Jong, K. P. Hydrotalcites supported on carbon nanofibers as solid base catalysts for the synthesis of MlBK. J. Catal. 2005, 236 (1), 91-100.

(33) Angelescu, E.; Pavel, O. D.; Birjega, R.; Zavoianu, R.; Costentin, G.; Che, M. Solid base catalysts obtained from hydrotalcite precursors, for 
Knoevenagel synthesis of cinamic acid and coumarin derivatives. Appl. Catal. A 2006, 308, 13-18.

(34) Veldurthy, B.; Clacens, J. M.; Figueras, F. Magnesium-lanthanum mixed metal oxide: A strong solid base for the Michael addition reaction. Adv. Synth. Catal. 2005, 347 (6), 767-771.

(35) Bontchev, R. P.; Liu, S.; Krumhansl, J. L.; Voigt, J.; Nenoff, T. M. Synthesis, characterization, and ion exchange properties of hydrotalcite $\mathrm{Mg}_{6} \mathrm{Al}_{2}(\mathrm{OH})_{16}(\mathrm{~A})_{x}\left(\mathrm{~A}^{\prime}\right)_{2-x} \cdot 4 \mathrm{H}_{2} \mathrm{O}\left(\mathrm{A}, \mathrm{A}^{\prime}=\mathrm{Cl}^{-}, \mathrm{Br}^{-}, \mathrm{I}^{-}\right.$, and $\mathrm{NO}_{3}{ }^{-}, 2 \geq x$ $\geq 0)$ derivatives. Chem. Mater. 2003, 15 (19), 3669-3675.

(36) Costantino, U.; Coletti, N.; Nocchetti, M.; Aloisi, G. G.; Elisei, F. Anion exchange of methyl orange into $\mathrm{Zn}-\mathrm{Al}$ synthetic hydrotalcite and photophysical characterization of the intercalates obtained. Langmuir 1999 15 (13), 4454-4460.

(37) Mohanambe, L.; Vasudevan, S. Anionic clays containing antiinflammatory drug molecules: Comparison of molecular dynamics simulation and measurements. J. Phys. Chem. B 2005, 109 (32), 1565115658.

(38) Roelofs, J.; Lensveld, D. J.; van Dillen, A. J.; de Jong, K. P. On the structure of activated hydrotalcites as solid base catalysts for liquidphase aldol condensation. J. Catal. 2001, 203 (1), 184-191.

(39) Ogawa, M.; Kaiho, H. Homogeneous precipitation of uniform hydrotalcite particles. Langmuir 2002, 18 (11), 4240-4242.

(40) van Dillen, A. J.; Geus, J. W.; L.A.M., H.; van der Meijden, J. Proc. Int. Congr. Catal., 6th 1977, 677.

(41) Toebes, M. L.; van Heeswijk, E. M. P.; Bitter, J. H.; van Dillen, A. J.; de Jong, K. P. The influence of oxidation on the texture and the number of oxygen-containing surface groups of carbon nanofibers. Carbon 2004, 42 (2), 307-315.

(42) Winter, F.; Bezemer, G. L.; van der Spek, C.; Meeldijk, J. D.; van Dillen, A. J.; Geus, J. W.; de Jong, K. P. TEM and XPS studies to reveal the presence of cobalt and palladium particles in the inner core of carbon nanofibers. Carbon 2005, 43 (2), 327-332.

(43) Cavani, F.; Trifiro, F.; Vaccari, A. Hydrotalcite-type anionic clays: Preparation, properties and applications. Catal. Today 1991, 11 (2), 173.

(44) Winter, F. Hydrotalcite-Based Catalysts for the Synthesis of Methyl Isobutyl Ketone. Ph.D. Thesis, Utrecht University, Utrecht, The Netherlands, 2006.

(45) Costantino, U.; Marmottini, F.; Nocchetti, M.; Vivani, R. New synthetic routes to hydrotalcite-like compounds-Characterisation and properties of the obtained materials. Eur. J. Inorg. Chem. 1998, (10), 14391446.

(46) Kovanda, F.; Kolousek, D.; Cilova, Z.; Hulinsky, V. Crystallization of synthetic hydrotalcite under hydrothermal conditions. Appl. Clay Sci. 2005, 28 (1-4), 101-109.

(47) Kim, S.-N.; Son, W.-J.; Choi, J.-S.; Ahn, W.-S. $\mathrm{CO}_{2}$ adsorption using amine-functionalized mesoporous silica prepared via anionic surfactant-mediated synthesis. Microporous Mesoporous Mater. 2008, 115 (3), 497-503.

(48) Bailly, M.-L.; Chizallet, C.; Costentin, G.; Krafft, J.-M.; LauronPernot, H.; Che, M. A spectroscopy and catalysis study of the nature of active sites of $\mathrm{MgO}$ catalysts: Thermodynamic Brønsted basicity versus reactivity of basic sites. J. Catal. 2005, 235 (2), 413-422.

(49) Mario Chiesa, E. G. Carbon Dioxide Activation by Surface Excess Electrons: An EPR Study of the $\mathrm{CO}_{2}{ }^{-}$Radical Ion Adsorbed on the Surface of $\mathrm{MgO}$. Chem.-Eur. J. 2007, 13 (4), 1261-1267.

(50) Fishel, C. T.; Davis, R. J. Use of catalytic reactions to probe $\mathrm{Mg}-$ Al mixed oxide surfaces. Catal. Lett. 1994, 25 (1), 87-95.

(51) Schneider, W. F. Qualitative differences in the adsorption chemistry of acidic $\left(\mathrm{CO}_{2}, \mathrm{SO}_{x}\right)$ and Amphiphilic $\left(\mathrm{NO}_{x}\right)$ species on the alkaline earth oxides. J. Phys. Chem. B 2004, 108 (1), 273-282.

(52) Florez, E.; Fuentealba, P.; Mondragon, F. Chemical reactivity of oxygen vacancies on the $\mathrm{MgO}$ surface: Reactions with $\mathrm{CO}_{2}, \mathrm{NO}_{2}$ and metals. Catal. Today 2008, 133, 216-222.

(53) Pacchioni, G. Physisorbed and Chemisorbed $\mathrm{CO}_{2}$ at Surface and Step Sites of the $\mathrm{MgO}(100)$ Surface. Surf. Sci. 1993, 281 (1-2), 207-219.

(54) Meixner, D. L.; Arthur, D. A.; George, S. M. Kinetics of desorption, adsorption, and surface diffusion of $\mathrm{CO}_{2}$ on $\mathrm{MgO}(100)$. Surf. Sci. 1992, $261(1-3), 141-154$.

(55) Daub, C. D.; Patey, G. N.; Jack, D. B.; Sallabi, A. K. Monte Carlo simulations of the adsorption of $\mathrm{CO}_{2}$ on the $\mathrm{MgO}(100)$ surface. J. Chem. Phys. 2006, 124 (11), 114706.

(56) Preda, G.; Pacchioni, G.; Chiesa, M.; Giamello, E. Formation of $\mathrm{CO}_{2}^{-}$Radical Anions from $\mathrm{CO}_{2}$ Adsorption on an Electron-Rich $\mathrm{MgO}$ Surface: A Combined ab Initio and Pulse EPR Study. J. Phys. Chem. C 2008, 112 (49), 19568-19576.

(57) McKenzie, A. L.; Fishel, C. T.; Davis, R. J. Investigation of the Surface Structure and Basic Properties of Calcined Hydrotalcites. J. Catal. 1992, 138 (2), 547-561.

(58) Virnovskaia, A.; Morandi, S.; Rytter, E.; Ghiotti, G.; Olsbye, U. Characterization of $\mathrm{Pt}, \mathrm{Sn} / \mathrm{Mg}(\mathrm{Al}) \mathrm{O}$ Catalysts for Light Alkane Dehydrogenation by FT-IR Spectroscopy and Catalytic Measurements. J. Phys. Chem. C 2007, 111 (40), 14732-14742.

(59) Karlsen, E. J.; Nygren, M. A.; Pettersson, L. G. M. Comparative study on structures and energetics of $\mathrm{NO}_{x}, \mathrm{SO}_{x}$, and $\mathrm{CO}_{x}$ adsorption on alkaline-earth-metal oxides. J. Phys. Chem. B 2003, 107 (31), 7795-7802.

(60) Jensen, M. B.; Pettersson, L. G. M.; Swang, O.; Olsbye, U. $\mathrm{CO}_{2}$ sorption on $\mathrm{MgO}$ and $\mathrm{CaO}$ surfaces: A comparative quantum chemical cluster study. J. Phys. Chem. B 2005, 109 (35), 16774-16781.

(61) Chimentao, R. J.; Abello, S.; Medina, F.; Llorca, J.; Sueiras, J. E.; Cesteros, Y.; Salagre, P. Defect-induced strategies for the creation of highly active hydrotalcites in base-catalyzed reactions. J. Catal. 2007, 252 (2), 249-257.

(62) Climent, M. J.; Corma, A.; Iborra, S.; Epping, K.; Velty, A. Increasing the basicity and catalytic activity of hydrotalcites by different synthesis procedures. J. Catal. 2004, 225 (2), 316-326.

Received for review July 13, 2009 Revised manuscript received November 4, 2009 Accepted December 2, 2009

IE901114D 